\title{
An uncommon long-term survival case of primary cardiac leiomyosarcoma
}

\author{
Meriam Glaoui ${ }^{1}$, Zineb Benbrahim ${ }^{2}$, Rhizlane Belbaraka ${ }^{3}$, Sara Naciri ${ }^{4}$, Hassan Errihani $^{4}$ and Axel Lescene ${ }^{2}$
}

\begin{abstract}
Primary cardiac sarcoma is a rare aggressive entity. It constitutes the second most common type of primary cardiac neoplasms. Its management has largely been guided by small retrospective series with a median survival of 6 months. Here, we discuss a unique case of 8-year survival cardiac leiomyosarcoma managed by surgical and adjuvant therapy.
\end{abstract}

Keywords: Cardiac neoplasm, Leiomyosarcoma, Survival

\section{Background}

Primary cardiac sarcomas constitute a rare entity. At present, only a few hundred primary cardiac sarcomas have been reported, most of which are based on autopsy series. Despite this rarity, they are the second most common type of primary cardiac neoplasm and account for most of the malignant primary cardiac tumors. Primary cardiac sarcomas are aggressive tumors that generally do not produce symptoms until they are locally advanced. Their management has largely been guided by small retrospective series and non-cardiac sarcoma management principles. However, the prognosis of primary cardiac sarcomas in general remains poor according to the current medical literature. The median survival in patients with cardiac sarcomas has been reported to be about 6 months with a mean of 11 months. Here, we discuss a unique case of 8-year survival cardiac leiomyosarcoma managed by surgical and adjuvant therapy.

\section{Case presentation}

A 47-year-old man presented with acute pulmonary edema with severe progressive dyspnea and orthopnea. He had a 10 pack-year history of cigarette smoking, but no other medical or familial conditions. Chest radiograph showed a small right-sided pleural effusion. Electrocardiogram revealed sinus tachycardia without any conduction abnormalities. Transthoracic echocardiography

\footnotetext{
* Correspondence: zineb247@hotmail.com

${ }^{2}$ Gustave Roussy Institute, 114 Rue Édouard Vaillant, 94805 Villejuif, France Full list of author information is available at the end of the article
}

and cardiac magnetic resonance imaging (CRMI) showed a tumor $(4 \times 5 \mathrm{~cm})$ occupying the side wall of the right atrium budding into the lumen (Figure 1).

Through a median sternotomy, a radical excision of the neoplasm was performed; the atrial wall was reconstructed using a bovine pericardial patch. The post-operative course was unremarkable and the anatomical pathology analysis revealed fusiform cells with considerable nuclear pleomorphism and mitotic activity. The immunohistochemical study was positive to vimentin, desmin, actin, and HHF-35, and negative for PS-100, cytokeratin, and hormone receptors. The final diagnosis was cardiac leiomyosarcoma. Adjuvant chemotherapy with doxorubicin $\left(60 \mathrm{mg} / \mathrm{m}^{2}\right.$ day 1) and ifosfamide ( $3 \mathrm{~g} / \mathrm{m}^{2}$ day 1 and 2) were realized and MRI after the four cycles did not show any sign of local or distant relapse.

Seven years after the first operation, local recurrence with a metastatic paravertebral soft tissue mass was revealed by magnetic resonance imaging. There was no lung metastasis. The patient received antalgic vertebral radiotherapy with systemic palliative chemotherapy consisting of oral cyclophosphamide. One year later, he died of progressive disease and multiorgan failure.

\section{Conclusions}

Primary leiomyosarcomas of the heart [1] are extremely rare, accounting for $0.019 \%$ of all malignant cardiac neoplasms in autopsy studies [2]. They typically occur in the fourth decade with no sex predilection. As all other cardiac sarcomas, primary leiomyosarcoma of the heart are usually asymptomatic until an advanced stage. Consequently, the 


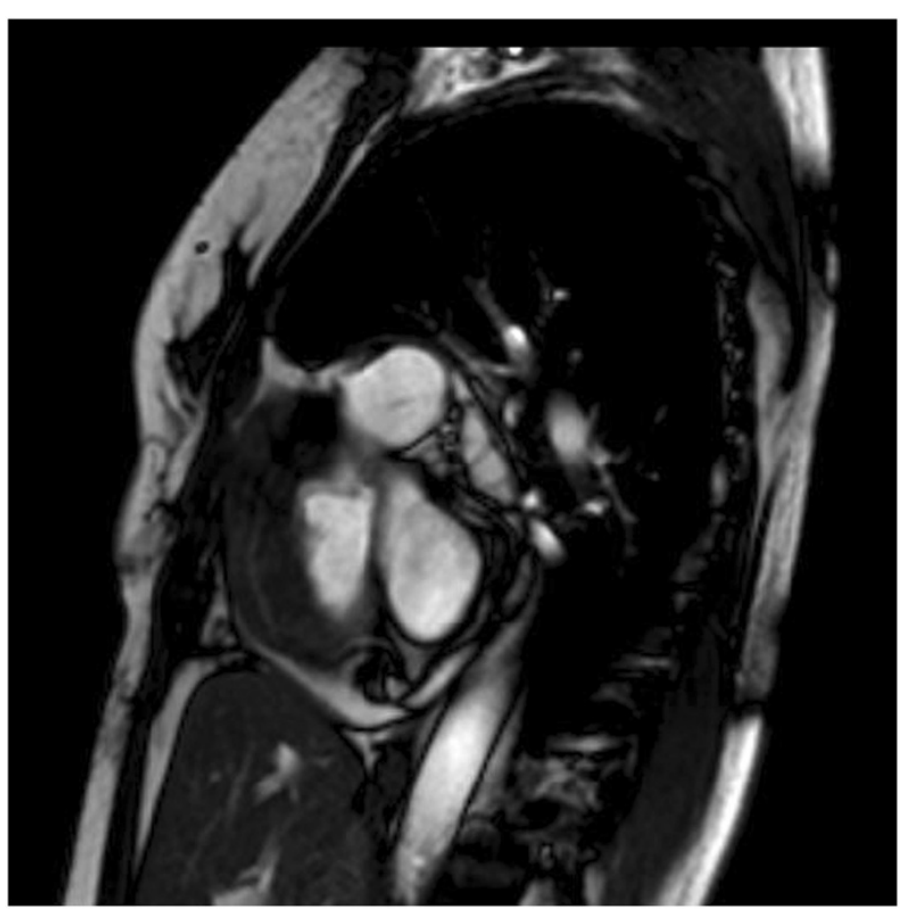

Figure $1 \mathrm{MRI}$ T2 cuts, minor axis passing throughout the right atrium showing an irregular isosignal wall thickening of the side wall of the right atrium.

diagnosis is often clinically delayed until hemodynamic consequences and embolisms. Cardiac MRI is the gold standard complementary exam to distinguish malignant lesions and assess the resectability of the tumors.

Due to the small series reporting this disease, the treatment guidelines are not well defined. Radical surgical interventions seem to offer the best outcome; however, a complete surgical resection is often difficult to achieve. The role of adjuvant chemotherapy and radiotherapy to prolong survival in this group of patients is not clear [3-5]. Another therapeutic option is orthotopic heart transplantation. In this case, the work up should include a total body positron emission tomography and CT scans to exclude distant metastases [6]. Thus, the adequate multimodal treatment strategy should be discussed in a pluridisciplinary meeting in order to improve survival. Prognosis is poor. Nevertheless, it seems that for patients who survived the initial surgery, the prospect for long-term survival is very promising. The present case has been discussed in view of rarity of longterm survival in cardiac leiomyosarcomas since our patient is the longest survivor reported thus far in the English language medical literature with good interim quality of life (Table 1).

Table 1 Cases of cardiac leiomyosarcoma reported in the literature with available data of treatment modalities and survival

\begin{tabular}{|c|c|c|c|c|c|c|c|}
\hline Reference & Age/sex & Origin site & Tumor size & Grade & Margin status & Treatment received & Survival (months) \\
\hline [7] & $64 / F$ & Left atrium & 17 & 3 & Positive & Curative surgery and adjuvant chemotherapy & 9 \\
\hline [7] & $54 / \mathrm{M}$ & Right atrium & 6 & 3 & Positive & Curative surgery and adjuvant chemotherapy & 13 \\
\hline$[5]$ & $45 / F$ & Left atrium & 10 & 3 & Positive & Palliative surgery & 5 days \\
\hline$[8]$ & $46 / M$ & Left ventricle & - & $2-3$ & - & Palliative chemotherapy & 13 \\
\hline$[8]$ & $42 / F$ & Left ventricle & - & 3 & - & Palliative chemotherapy & 18 \\
\hline [9] & $63 / F$ & Right ventricle & 4 & & & Curative surgery & 36 \\
\hline$[10]$ & $86 / F$ & Left atrium & 4 & - & - & Curative surgery & 15 \\
\hline$[11]$ & $74 / \mathrm{M}$ & Left atrium & - & - & Positive & Curative surgery and adjuvant radiotherapy & 8 \\
\hline$[12]$ & $54 / F$ & Right atrium & & & & Curative surgery & Few hours \\
\hline [13] & $35 / F$ & Right atrium & 5.6 & 3 & Positive & Surgery and palliative chemotherapy & 10 \\
\hline
\end{tabular}




\section{Consent}

Oral informed consent was obtained from the patient for publication of this case report and any accompanying images.

\section{Competing interests}

The authors declare that they have no competing interests.

\section{Authors' contributions}

The work presented here was carried out in collaboration between all authors. MG, ZB, RB, and SN analyzed the data and wrote the manuscript. HE and $\mathrm{AL}$ participated in reviewing the scientific literature and contributed to the final version of the manuscript. All authors read and approved the final manuscript.

\section{Author details}

'Department of Medical Oncology, clinique le littoral, salaj 3, Ain diab., Casablanca, Morocco. ${ }^{2}$ Gustave Roussy Institute, 114 Rue Édouard Vaillant, 94805 Villejuif, France. ${ }^{3}$ Department of medical oncology, Mohamed VI University hospital, Faculty of medicine of Marrakesh, Cadi ayad University, BP7010 Sidi Abbad, Marrakesh, Morocco. ${ }^{4}$ Department of Medical Oncology, National institute of oncology, hay irfane, 10100, Rabat, Morocco.

Received: 20 January 2013 Accepted: 20 October 2014

Published: 10 November 2014

\section{References}

1. Butany J, Nair V, Nassmuddin A, Nair GM, Catton C: Cardiac tumors: diagnosis and treatment. Lancet 2005, 6:219-228.

2. McAllister HA Jr, Fenoglio JJ: Tumors of the cardiovascular system. Atlas of tumor pathology, 2nd series, Fascicle 15. Washington, DC: Armed Forces Institute of Pathology; 1978.

3. Burke AP, Cowan D, Virmani R: Primary sarcomas of the heart. Cancer 1992, 69(2):387-395

4. Boey S, Tribouilloy C, Lesbre JP, Stankowiak C, Copin MC, Haffreingue E, Espriet G: Leiomyosarcome du l'oreillette gauche opere'. Arch Mal Coeur 1994, 87:291-294.

5. Zhang PJ, Brooks JS, Goldblum JR, Yoder B, Seethala R, Pawel B, Gorman JH, Gorman RC, Huang JH, Acker M, Narula N: Primary cardiac sarcomas: a clinicopathologic analysis of a series with follow-up information in 17 patients and emphasis on long-term survival. Hum Pathol 2008, 39:1385-1395.

6. Winther C, Immermans-Wielenga V, Daugaard S, Mortensen SA, Sander K, Andersen CB: Primary cardiac tumors: a clinicopathologic evaluation of four cases. Cardiovasc Pathol 2011, 20:63-67.

7. Kim CH, Dancer JY, Coffey D, Zhai QJ, Reardon M, Ayala AG, Ro JY: Clinicopathologic study of 24 patients with primary cardiac sarcomas: a 10-year single institution experience. Hum Pathol 2008, 39:933-938.

8. Mayer F, Aebert H, Rudert M, Königsrainer A, Horger M, Kanz L, Bamberg M, Ziemer G, Hartmann JT: Primary malignant sarcomas of the heart and great vessels in adult patients-a single-center experience. Oncologist 2007, 12:1134-1142.

9. Kim JD, Kim JS, Hwang TS, Shin JK, Song MG: Surgical management of recurrent leiomyosarcoma in heart Korean. J Thorac Cardiovasc Surg 2014, 47(1):35-38.

10. Andersen RE, Kristensen BW, Gill S: Cardiac leiomyosarcoma, a case report. Int J Clin Exp Pathol 2013, 6(6):1197-1199.

11. Nakanishi H, Furukawa K, Noguchi R, Furutachi A, Itoh M Kamohara K, Okazaki Y, Yamasaki F, Morita S: Primary cardiac leiomyosarcoma originating from the left atrium. Kyobu Geka 2012, 65(12):1057-1061
12. Lotze U, Reponova J, Muth G, Oltmanns G, Reich HC, Etzrodt G, Kaiser WA, Mutschke O, Ortmann M, Stippel D, Wahlers T: Leiomyosarcoma of the inferior vena cava extending into the right atrium. A rare differential diagnosis of a right atrial tumor with fatal outcome. Herz 2012, 37(5):573-578.

13. Jellis C, Doyle J, Sutherland T, Gutman J, Maclsaac A: Cardiac epithelioid leiomyosarcoma. Clin Cardiol 2010, 33(6):E6-E9.

doi:10.1186/1477-7819-12-338

Cite this article as: Glaoui et al:: An uncommon long-term survival case of primary cardiac leiomyosarcoma. World Journal of Surgical Oncology 2014 12:338

\section{Submit your next manuscript to BioMed Central and take full advantage of:}

- Convenient online submission

- Thorough peer review

- No space constraints or color figure charges

- Immediate publication on acceptance

- Inclusion in PubMed, CAS, Scopus and Google Scholar

- Research which is freely available for redistribution

Submit your manuscript at www.biomedcentral.com/submit
C Biomed Central 